Original paper UDC 159.955(045)(083.77)

doi: $10.21464 / \mathrm{sp} 31208$

Received February $1^{\text {st }}, 2016$

\title{
Daniel Bučan
}

Laginjina 3, HR-10000 Zagreb

danbucan.novi@gmail.com

\section{'Active Intellect' in Avempace and Averroës: An Interpretative Issue}

\begin{abstract}
This essay is about the understanding of the notion of active intellect in Ibn Bāğğa (Avempace) and Ibn Rušd (Averroës). The traditional interpretation of both Avempace's and Averroës' concept of active intellect is that they both understand it as the lowest celestial intelligence which is dator formarum, and that man thinks and cognizes intelligibles only by "connecting" with it in a quasi-mystic way; cognition being the active intellect's granting ideas (formae or concepts) to man's intellect. The author believes that both in Avempace's and Averroës' theory of cognition the notion of active intellect is only the highest function of human intellect, not a celestial entity. Based on such a presumption, as well as on the analysis of his theory, Avempace's notion of ittisāa bi-'aql fa"āl is interpreted not as a kind of mystic "conjunction" or "union" with a separate celestial entity, but as reaching the highest level of man's intellect function in the continuity of the process of thinking. The same goes for Averroës'theory, which is quite clearly presented in his Epistle on the Possibility of Conjunction with the Active Intellect, where one can find practically direct confirmation for such an interpretation, because Averroës says that "conjunction with it [i.e. active intellect] seems to resemble more the conjunction of form in matter than it does the conjunction of agent with effect. The well-known difference between agent and effect is that the agent is external, but here there is no external agent", or that active intellect "conjoins with us from the outset by conjunction of in-existence". The author concludes that the issue of the active intellect in Islamic philosophy is not disambiguous - for different thinkers it was a different concept - only the function of the active intellect is always one and the same: producing ideas.
\end{abstract}

\section{Keywords}

cognition, intellect, hylic intellect, intellect in actu, active intellect

\section{Understanding active intellect as dator formarum}

The first Muslim thinker who elaborated the understanding of the so-called 'active intellect', which became the general understanding of it within Islamic philosophy, was Al-Fārābī (*cca. $870 \dagger 550)$. He wrote about it in many of his works, especially in his Risālatu-l-'aql (Epistle on the Intellect) and in AlMadīna al-Fädila (The Virtuous City).

Al-Fārābī defines 'active intellect' in opposition to the human intellect. The human intellect is called 'material intellect' or 'passive intellect' because it is a disposition in matter, ready to receive imprints of intelligibles, prior to which it is not intellect in actu. To become intellect in actu it needs something which transfers it from potentiality to actuality by conferring intelligibles to it. That which transfers 'material' or 'passive' intellect into actuality, says Al-Fārābī, is separated from matter and it provides the 'passive intellect' with something like the light that the Sun provides to our sight. Through the influence of this 
'separate intellect' on the 'material intellect' the things which were only potentially intelligible become actually intelligible, and 'passive intellect' becomes intellect in actu; thanks to this function this 'separate intellect' (as opposed to the 'passive intellect') is called 'active intellect' ('aql fa " $\bar{a} l$ ).

Besides likening the 'active intellect' to the light of the Sun and likening its function to that which enables the faculty of seeing, whose description is similar to Aristotle's De anima, III, 5 (430a15), ${ }^{1}$ Al-Fārābī defines it as the lowest transcendent celestial intellect in ranking order emanating from the First Principle. As such it is not only the agent that transfers 'material' or 'passive' intellect into actuality, but acts upon the whole sublunar world as dator formarum.

Al-Fārābi owes much of his ideas on the functions of the soul to Alexander of Aphrodisias, who identifies Aristotelian noūs poietikos with the mind of the First Cause, but it is most likely that Neoplatonist's Marinus of Sichem's description of the active intellect as daimonion or angelikon has to be credited for Al-Fārābī's definition of the active intellect as the lowest, tenth emanation from the First Principle, ${ }^{2}$ whose emanations were equated with the angels. (As such a divine celestial entity, in the translations of Arabic philosophical texts, it is usually called the Active intellect - with a capital $A$ in translations from Arabic - in order to stress its being of divine origin). It could be said that Al-Fārābi - and after him other Muslim philosophers through Neoplatonist influences - in a way exploited Aristotle's general theory of cognition for cosmological purposes by using the term 'active intellect' for naming (and identifying it with) the lowest emanation from the First Principle acting in the sublunar world. ${ }^{3}$

Be that as it may, in regard to the active intellect's function in man's thinking and cognizing, Al-Fārābī's theory means that man thinks and cognizes intelligibles thanks to the action of a separate and divine entity (which, in order to preserve Aristotle's position in Al-Fārābī's philosophical ideology, ${ }^{4}$ could be interpreted as Aristotle's thyraten noūs).

Such an interpretation of the role ascribed to Active Intellect has been accepted by virtually all Muslim philosophers. In such an interpretation the process of thinking and cognizing depends on the conjunction of human intellect with the Active Intellect, which Al-Fārābī identified as the rūh al-qudus (the Holy Spirit, i.e. the Angel of Revelation) from the Qur'ān. This is the way most authors writing on Islamic philosophy interpret the theory of cognition of virtually all Muslim philosophers, ascribing it not only to Al-Fārābī and Avicenna $(* 980 \uparrow 1037)$ - to whom it genuinely belongs - but to Avempace (*cca. 1085 $\uparrow 1139)$ and Averroës $(* 1126 \uparrow 1198)$ - whose texts cast at least a serious doubt on such an interpretation - as well. This interpretation will be questioned here in reference to Avempace's Risāla ițtișāl al- 'aql bi-l-insā̄n ${ }^{5}$ and Averroës' Epistle on the Possibility of Conjunction with the Active Intellect which is known only thanks to a mediaeval Hebrew translation, commented by fourteenth-century Hebrew philosopher Moses Narboni. ${ }^{6}$ Avempace's risāla is traditionally translated as Conjunction of Intellect with Man (how this title should be understood and translated is the subject of this article).

\section{Avempace's understanding of intellect and levels of cognition}

Let us see what Avempace's risāla is about.

He begins the risāla by discussing the meaning of one of its basic terms, which is the term wähid (=one; in the sense of 'one' and in the sense of 'one 
as indivisible', as well as in the sense of 'one and the same'). He asks of what it could be said that it is 'one', and shows that it can be said of many things: of that which is continued, of that which is compact, of that which is a whole, and so on. But he stresses that concerning this risāla he will discuss, as predicted, man, who is 'one' ('one' as in 'one and the same'), regardless of all the changes he goes through in his life. This, says Avempace, means that man is 'one' thanks to something which is not perceived by the senses, as opposed to the visible and perceivable changes man goes through. That by which man is always one and the same is his 'first mover', i.e. the soul; and the soul is man's first mover when the intellect (as its faculty) becomes in actu-man is an individual thanks to thinking:

"By cognizing the concepts there comes to be an aspiration which moves to thinking and to that which comes forth from it - he is an individual man thanks to this not thanks to the concepts."7

So, that which is called man's intellectual faculty - which is the subject (hypokeimenon) of thinking - is intellect in actu (intellect which received intelligibles), and the soul is individual man's "first mover" only because of his intellect.

Avempace continues by asking whether the intellectual faculty as intellect in $a c t u$ is one for all men; is intellect in actu only one, so that all men are one? In that case, intellect would be one and the same in all men, like a magnet (which attracts metals) coated once by this material then by another material then by a third material, etc., which moves the metals every time, regardless of being coated by different materials. In order to answer this question, Avempace transposes it to the question of whether every concept (apprehended by the intellect) is one, and answers that, whether we answer yes or no, equally scandalous conclusions would result. If we say yes, "it necessarily results in an opinion which is similar to the opinion of those who speak of soul migration", 8 because the concept would "migrate" from man to man. If we say no, it would mean "that for the concept which I have and the concept which you have there is a concept common to those two, that this common concept would be in me and in you, and those two would have another concept com-

Where Aristotle says: "There is an intellect which is what it is by virtue of becoming all things, and another which is what it is by virtue of making all things - it is something like light: the light makes potential colours into actual colours."

Cf. Al-Fārābī, On the Perfect State, revised text with introduction, translation and commentary by Richard Walzer, Oxford University Press, Oxford 1985, "Commentary", p. 404-405.

Cf. Majid Fakhry, A History of Islamic Philosophy, Columbia University Press, New York 1983; second edition: Longman, London 1983, p. 88.

Which is: the essential agreement of Plato and Aristotle.
Ibn Bāğğa (Avempace), La conduite de l'isolé et deux autres épitres, introduction, critical edition of Arabic text, translation and commentary by Charles Genequand, Vrin, Paris 2010.

6

The Epistle on the Possibility of Conjunction with the Active Intellect by Ibn Rushd, with Commentary of Moses Narboni, a critical edition and annotated translation by Kalman P. Bland, The Jewish Theological Seminary of America, New York 1982.

7

Avempace, Itțișāl al-'aql bi-l-insān, § 15: Fa bi-ḥuṣūl al-ma'qūlāt taḥdut aš-šahwa almuharrika ilä-l-fikr wa mā yakūn 'anhu wa bi-hādihi huwa aš-šahș insān lā bi-tilka.

8

Ibid., § 25: lazima min dālika ra’y yašbihu ahl at-tanāsuh. 
mon to them, and so it would go on without an end". ${ }^{9}$ But Avempace differentiates between two types of concepts - a concept that is drawn (directly) from (perceived) individual things, and a concept that we can have of that which we never saw, for example of some exotic animal. This latter concept exists, in a way, as an abstract, and it is 'one in number' because it is not 'plural' by being connected with a multitude of real individuals from which it is drawn. For example, a person who knows the soul thanks to science, says Avempace, receives concepts which he draws from the science of the soul - which means from that 'which stands for the individual', i.e. from that which is both in the imagination and in 'common sense' (al-hiss al-muštarak) - and not from the soul itself. In other words, concepts drawn from science exist abstractedly, drawn from abstract concepts (in the way the 'individual' concepts are drawn from real individuals). ${ }^{10}$ From this we obtain an (indirect) answer to the question whether intellect is one for all men. In having connection with concepts drawn from real individual objects, and as such connected with (multiple) persons perceiving those individual objects, the intellect is not one for all men:

"By this, their intellects become multiple, and it is thought that intellect is multiple because that which is relative is relative to that which is related to it. And since the concept known to them is something which is relative, and because the individuals to which it is related are multiple, the relation of concept of man to the individual of that concept when the concept regards Ğarī is not identical with the relation of concept of man which regards Imrū' -1-Qays."11

On the other hand, when it has a purely abstract concept for its object (not a concept drawn from a real object), intellect is 'one'. ${ }^{12}$ In that case 'oneness' of human intellect is reflected in that which could be called abstract thinking:

"As regards intellect that for its object has itself, its concept does not have a spiritual form which would be its subject. [In such a case] intellect is understood as the concept of what is thought, and it is one and not multiple, because it is deprived of the relation by which the form is connected to the matter."13

There are three levels of cognition. The first one, which Avempace calls natural, is the level on which the concepts are connected to material forms, the level on which the concept is known in accordance to material objects (ordinary people being attentive first to the material forms and only after that to the concepts). The second is the level of theoretical cognition, which is the culmination of natural cognition (a theorist paying attention first of all to the concepts, paying attention to the material objects only because of their concepts). The third level is reached only by blessed ones, i.e. by those who directly contemplate the object of cognition, even identifying themselves with it. Taking the Sun as an example, Avempace explains that those having theoretical knowledge know concepts indirectly, as when we look at the reflection of the Sun in the water, and that ordinary people, on the first level, look at the image of the reflection of the Sun. On the third level, the blessed ones directly contemplate the object of cognition itself.

Seeing, says Avempace, is form impressed into sight. This form exists thanks to the light, because of it; it could impress itself into sight in the dark as well, not only in daylight. In cognition intellect has the same role light has in perceiving.

"To know something - he says - means that the person who knows knows the attribute of the object of knowledge, and this is its concept. To pass judgment on individual things [to which] that concept belongs in a certain moment is like acting: the faculty in which the concept is being impressed is like the eye, and the intellect [i.e. ' $a q l$, which - as we shall see further on in the text - means thinking as well; D. B.] is like seeing, which is the form impressed into sight. And in 
the same way that form exists thanks to the light - light is that which makes it exist in actu, so it is impressed into the sense thanks to the light - the same is true of the intellect in actu; it is by this intellect - which is not individual - that form becomes 'something' and becomes impressed into faculty. And as the form which is seen - not only the light - is the guide, so the guide that leads in the right direction is the intellect in actu." 14

Those who are on the level of natural cognition are similar to those who see the objects (or as Avempace says: the colours) in a cave only in the dark or in the shadow. Those who have theoretical knowledge are similar to those who have came out of the cave and into the daylight, and they see the objects (i.e. colours) as they are.

"But the situation of the blessed ones - he says - [is such that] there is nothing similar to their seeing, because they identify themselves with the thing [they are looking at]." 15

This means that the highest form of cognition is the form in which the cognizant would identify himself/itself with the object of cognition. And this happens when the object of cognition of the intellect is the intellect itself - the insight attained is "man's ultimate self-sufficient happiness, and then the most sublime objects of speculation are contemplated directly". ${ }^{16}$ Speaking of this form of cognition, Avempace says that it is "the pinnacle of life". This form of cognition is the most perfect form of 'being one' (tawahhud) with the object of cognition. It is that form of cognition that can be reached by 'the solitary' (al-mutawahhidid) from his risāla on 'the solitary being'.

Thus the subject of this risāla is intellect as the object of cognition - the cognized intellect. And since man is an individual person thanks to intellect, i.e.

Ibid., § 26: an yakūna li-l-ma' qūl allad̄ī 'indī wa 'indak ma'qūl yu'ammihā wa dālika-l-ma'qūl yakūnu ayḍan 'indī wa 'indak fa yakūnu lahu ma’qūl āḩar wa dêalika ilä mā lā nihāya.

10

This refers to what Avempace differentiates (in Tadbīr al-mutawahhid) as "universal spiritual forms" and "individual spiritual forms" (i.e. forms drawn from real objects); "universal spiritual form" is 'one in number', and "individual spiritual forms" are not "one in number'.

11

Ibid., § 37: Wa bi-dālika tatakattar 'uqūluhum fa-yuẓann anna al-‘aql kațīr wa dālika anna al-muḍāa muḍāf li-mā huwa muḍāf ilayhi wa li-mā kāna al-ma'na al-ma'qūl 'indahum muḍāfan wa ašhāṣ iḍāfatuhu kațīra fainna idāfatahu ma'qūl al-insān ilä ašhāșihi 'inda Ğarīr gayr iḍāfatihi ma'qūl al-insān ilä ašḩäșihi ‘inda Imri' -1-Qays.

12

Taking different possibilities into account the word ' $a q l$ and how it can be understood, see further in this article where it is shown that ' $a q l$ translates not only the Greek noūs, but the Greek noésis as well. This difference in understanding of the term ' $a q l$ may be of importance in contexts such as the context of this and previous citations, and, as a matter of fact, in any context in which 'intellect' can be understood as 'intellection'.
13

Avempace, Itțiṣāl al- 'aql bi-l-insān, § 38: Faamā al-'aql alladīi ma'qūluhu huwa bi-'aynihi fa-d̄ālika laysa lahu șūratan rūḥāniyyatan mawḍ̂̀'atan lahu fa-l-'aql yufham minhu mā yufham min al-ma'qūl wahuwa wāhid gayr mutakattirir id qad halā min al-ị̣afa allatī yunāsib bihā aṣ-șūra fī-l-hayūlä.

14

Ibid., § 46: Wa ma'nä-1-'ilm bi-’š-šay' huwa an yakūna 'inda-1-'ālim bihi mahmūlahu wa huwa ma'qūluhu wa-l-qaḍā' 'alä ašḩāṣ dēlika1-ma'qūl fĩ waqt dūna waqt yašbihu as-sa'y wa-l-quwwa allatī yartasimu fīha al-ma'qūl tašbihu al-'ayn wa-1-‘aql yašbihu al-ibșār wa huwa aș-șūra al-murtasima fî-1-bașr wa kamā anna tilka-ṣ-șūra hiya bi-ḍ-ḍū' fa-inna aḍ-ḍ̄'a yūğaduha bi-1-fi'l wa bihi yartasimu fì-1-hāssa fa-kad̄ālika al-‘aql bi-1-fi’l bi-d̄ālika ‘aql alladī laysa lahu šahs yușīu šay’an-mā wa yartasimu fī-l-quwwa wa kamā anna hādihi aṣ-ṣūra al-mubșara hiya hg-hādiya lā aḍ-ḍ̄ù al-mufrad kad̄ālika hāḍa al-'aql bi-lfi'll huwa al-hādì.

15

Ibid., § 48: Wa amā ḥāl as-su'adā’ fa-laysa lahā fî-l-ibṣār šibh id yuṣīūna hum aš-šay’.

16

Ibid., § 38: Wa huwa as-sa'āda al-qușwä alinsāniyya al-mutawaḥhịida wa 'inda dālika yušahidu al-mušāhid al-'aẓīma. 
thanks to thinking, ${ }^{17}$ it could be said that the risāla is about man's self-cognizance. (In that respect the text makes a whole with Avempace's other two risālāt - with the Risāla al-wid̄a ' and Tadbìr al-mutawahhid - because in this risāla, as well as in the other two, the subject really is how man can rise up to his ultimate perfection by the intellectual and moral means at his disposal.)

\section{Possible different interpretations of the 'conjunction' with the active intellect}

Now something should be said about different possible interpretations of the idea of 'conjunction with the active intellect'.

Avempace mentions the 'active intellect' in his Epistle on the Solitary Being, and does not mention it in the risāla under consideration here, namely the risāla On the Conjuction of the Intellect with Man. Still, virtually all those who have commented on his theory of cognition - starting with his contemporary Ibn Tufayl (*cca. $1105 \dagger 1185)$ - say he sees the process of thinking as 'union' with the Active Intellect (as Al-Fārābī and Avicenna do). So, although he does not mention the 'active intellect' in the risāla On the Conjunction of Intellect with Man, it is still of interest to try to investigate what his understanding of the 'active intellect' - which plays the key role in cognition theory of all Arab philosophers - might be.

The fact that Avempace does not mention the 'active intellect' in this risāla alone might suggest that his understanding of it is different from that of AlFārābī. In this risāla he speaks of a "conjunction of intellect with man", and this suggests that Genequand's interpretation of the meaning of the word ițtișāl as 'continuity' rather than 'conjunction'18 - bearing in mind the continuity of man's thinking - is acceptable. Still, Avempace does mention 'active intellect' in his other risālāt. For example, in the risāla On the Solitary Being (Tadbìr al-mutawahhid) - where he alternatively uses expressions 'aql fä'il and 'aql fa" $\bar{a} l$ - he says that spiritual forms which are not procured by senses and nature are procured by the 'active intellect', and that by reaching the level of the 'active intellect' man reaches his highest perfection and his utmost happiness. So, this means that to Avempace the concept of the 'active intellect' was, of course, known, and that he uses it (although not in a perfectly consistent way), and this is reason enough to try to see what he had in mind when using the concept.

As has been already said, most of those who have commented on Avempace think he understood the concept of 'active intellect' as did Al-Fārābī, i.e. as a name for the tenth (the lowest) of "celestial intellects", which emanate from the First Principle, and the concept of 'conjunction' as a form of "mystic" union of man's intellect with that tenth celestial intellect. Avempace was interpreted in this way by Ibn Țufayl and by Averroës, and almost all modern scholars - such as Al-'Alawī, A. Altmann, C. d'Ancona, E. I. J. Rosenthal and others (except $\mathrm{Ch}$. Genequand) - adhere to that interpretation. For example, in the History of Islamic Philosophy, ${ }^{19}$ in which a chapter is dedicated to Avempace, Lenn E. Goodman says that Avempace - like Al-Fārābī and Avicenna - believes that knowledge is not gained only by the senses, that universal and necessary notions are realized through the assistance of the Active Intellect, which is the incorporeal celestial intelligence governing the sublunar sphere. As an argument in support of that, Goodman cites Avempace's text Wuqūf 'alä-l-'aql al-fa" $\bar{a} l$ (which could be translated as Comprehending the Active Intellect, or Understanding the Active Intellect). Contrary to that, Ch. 
Genequand believes firmly that Avempace's idea of the active intellect is essentially different. It is his opinion that Avempace does not conceive active intellect as a separate divine (celestial) entity, for which he believes to find textual support in the risāla On the Solitary Being, where Avempace puts 'active intellect' (calling it, as we said, alternatively ' $a q l f \bar{a}$ ' $i l$ and ' $a q l f a$ ' $\bar{a} l$ ) in the same category with so-called 'acquired intellect' ('aql mustafād); moreover, Genequand says that those intellects, according to Avempace, are one and the same entity. Based on this, Genequand elaborated his own interpretation of Avempace's understanding of the 'active intellect'. According to Genequand's interpretation, it is a theory of active intellect being simply the highest function of man's intellect. He says that Avempace, speaking of 'conjunction', does not have in mind a union or fusion with the Active Intellect as the tenth emanation from the First Principle in a "mystic", "vertical" sense, but has in mind only, so to speak, a "horizontal" continuity of man's intellect that has reached the highest level of its activity. So Genequand understands the title of the risāla differently, explaining that Itțiṣāl al- 'aql bi-l-insān should be understood as Continuity (or integrality) of the Intellect in Man, as an expression of the idea that man can think in a continuous manner. ${ }^{20}$ Although questioning the title of the risāla (which is Itțișāl al- 'aql bi-l-insān), reminding the reader that the risāla is a letter which has been "put into circulation" only after the death of the author, Genequand (in his edition of the Arab text and in his translation) keeps the traditionally established title (for obvious although not expressed reasons: Avempace's text bears this title in all bibliographies and library catalogues).

Although Genequand's interpretation (especially taking into account the text of this risāla and the text of other works by Avempace) is, to my mind, correct and well argued, I think yet another argument could be put forward. First, if we look in a dictionary searching for the meaning of the word 'aql, we will find that S. M. Afnan's dictionary ${ }^{21}$ says that Arabic 'aql translates not only the Greek noūs (Metaphysics 1074b20), but the Greek noèsis (Metaphysics 1074b36) as well. In support Afnan cites several examples, two of which could be cited here: "Thinking is not but cognition of the constitution of existing things and of their order" from Averroës" Tahäfut; ${ }^{22}$ or "When the rational soul acquires knowledge, its activity is called thinking", from Avicenna's Risāla an-nafs. ${ }^{23}$ Bearing this meaning of the word 'aql in mind, it would be possible to suppose that 'aql fa" $\bar{a} l$ can really be interpreted as an expression for the highest function of intellect, that the expression itttișāl $b i-l$ - 'aql fa " $\bar{a} l$ points to the highest form of thinking. Afnan's dictionary, for example, 'aql fa ' $\bar{a} l$ - beside the Latin translation 'intellectus agens' - cites the English translation 'active intelligence' and the French translation 'intel-

17

Cf. ibid., $\S 15$.

18

Cf. Ibn Bāğğa, La conduite de l'isolé et deux autres épîtres, p. 63.

19

Cf. History of Islamic Philosophy, ed. by Seyyed Hossein Nasr and Oliver Leaman, Routledge, London - New York 2007.

20

Cf. Ibn Bāğğa, La conduite de l'isolé et deux autres épîtres, "Introduction", p. 63.
21

Soheil M. Afnan, A Philosophical Lexicon in Persian and Arabic, Dar El-Mashreq Publishers, Beirut 1969.

22

Al-'aql laysa huwa šay'an aktar min idrāk niẓām al-ašyā’ al-mawğūda wa tartībaha.

23

An-nafs an-nāțiqa iḍā aqbalat ilä-l-'ulūm summiya fi'luha 'aqlan. 
ligence active'. The French dictionary Robert says that 'intelligence' does not mean only 'intellect', but 'l'ensemble des function mentales ayant pour objet la connaissance conceptuelle et rationelle' as well, and the American Webster says that 'intelligence' means 'capacity for reasoning, manifestation of such capacity', etc.

Such an understanding of the term 'aql dismisses the necessity of inveterate interpretation of the 'conjunction with the Active Intellect' as a mystic union with a divine entity. So, if we translate the word ' $a q l$ not as 'intellect' but as 'intelligence' (which means 'thinking' or 'reasoning'), we can certainly understand that Avempace's title can be translated/understood as Continuity of Thinking in Man, or Continuity of Man's Thinking.

Besides, dictionary says that the expression itțașala bi-nā means 'we came to know', which, as it seems, no translator or interpreter took into account. Based on this, it is plausible to understand the title Itțișal al-'aql bi-l-insān as Man's Cognizance of the Intellect. When Avempace's risāla has been read and understood, it will be clear that it is exactly about that; it is a treatise on how man cognizes his own intellect. And since, according to him, man becomes an individual thanks to his intellect or thanks to thinking, the treatise is about man's self-cognizance.

\section{What is Averroës's understanding of iț̣ișāl bi-l-'aql al-fa" $\bar{a} l$ ?}

The understanding of ittiișāl bi-l- 'aql al-fa 'äl as 'conjunction' or 'union' with the Active Intellect (as dator formarum) is so deep-rooted that it is, as we already said, almost automatically ascribed to all Muslim philosophers, regardless of their general philosophical "ideology", equally to Al-Fārābī and Avicenna as to Avempace and Averroës. But, as we have seen, it is reasonable enough to reject such an interpretation of Avempace's noetic theory, and we will try to show that it can be equally rejected concerning Averroës.

At the beginning of his Epistle on the Possibility of Conjunction with the Active Intellect, Averroës expresses the purpose of the risāla by saying:

"The purpose of this treatise is to investigate whether or not it is possible for the intellect within us, the so-called hylic [intellect], ultimately to apprehend the separate forms." 24

This and other statements in which there is mention of 'separate forms' was one of the main reasons why many interpreters, from Thomas Aquinas in the fourteenth century to Munk and Renan in the twentieth century, were convinced that Averroës' 'active intellect' was what Al-Fārābī, Avicenna, or Ibn Tufayl called 'Active Intellect', i.e. the tenth emanation from the First Principle. But the treatise itself provides arguments that this is not the case.

Speaking of the active intellect in his Epistle on the Possibility of Conjunction with the Active Intellect Averroës explicitly says:

"We say: that Active Intellect conjoins with us from the outset by conjunction of in-existence." 25

Essentially, this means that man's intellect is the subject, i.e. support or substratum, of the active intellect, the active intellect being the form conjoined with a subject! Averroës continues by saying:

"The [Active] Intellect, in this respect, is our form; but insofar as we cause the potential intellect within us $[\ldots]$ to pass from potentiality to actuality, it is as it were apart from the hylic intellect. The function and its conjunction with it seems to resemble more the conjunction of form in mat- 
ter than it does the conjunction of agent with effect. The well-known difference between agent and effect is that the agent is external, but here there is no external agent." 26

This quote states clearly that Averroës does not see the active intellect as the agent that is something apart from man's intellect and which causes man's thinking or reasoning from the outside, let alone from above.

Averroës compares the relation of active intellect to the hylic intellect ${ }^{27}$ with a potter "already immersed in the clay", so that the active intellect is a form which conjoins with the hylic intellect "in a conjunction of in-existence, not a conjunction of perception". ${ }^{28}$ With this he obviously wants to say that the active intellect is not reached by perceiving or cognizing it (as happens when man perceives or cognizes a celestial substance), because it is within the hylic intellect.

Why does not man apprehend the active intellect from the outset, although Averroës says that it is within us from the outset, that active intellect "conjoins with us from the outset by conjunction of in-existence"? The obstacle is the existence of the so-called 'acquired intellect', whose existence in man is caused by man's nature, and 'acquired intellect' is still defined by its potentiality. So only when it reaches its final entelechy (when it is divested of any potentiality) does it 'conjoin' with the active intellect in a new way, which is no longer a "conjunction of deficient with the perfect" but a "better conjunction", a conjunction that possesses a function that renders it unique. And that function "is nothing other than the conception of Active Intellect by the acquired intellect". ${ }^{29}$ What does this mean? It means that "conjunction by in-existence' (which is given from the outset) does not make the cognition of active intellect possible per se, i.e. just by being there. Only a "higher" form of conjunction, "conjunction by perception", 30 makes cognition of the active intellect possible.

But what of Averroës' statement that this higher form of conjunction by cognizance is "the apprehension of the separate, Active Intellect, by the acquired intellect"? ${ }^{31}$ It may seem that, in saying of active intellect that it is separate, he indeed might have had in mind a celestial, divine substance. Firstly, it should be noted that by 'separate' he (practically always) means 'abstract', i.e. 'separated from matter', and - according to Averroës' doctrine - intellect as such is 'separated from matter'. Secondly, as regards writing Active Intellect with a capital letter, it should be noted (and stressed) that it is up to the translator's free interpretation, since in Hebrew (in which the Epistle arrived

24

The Epistle on the Possibility of Conjunction with the Active Intellect by Ibn Rushd, p. 23 (Hebrew text on p. 4).

25

Ibid., p. 45 (Hebrew text on p. 43). Here as elsewhere in the passages cited from Averroës' text, the capital in Active Intellect is a translator's choice, which suggests that his interpretation of Averroës' understanding is different from ours.

26

Ibid. (italic D. B.).

Averroës' expression for man's intellect when it is in a state of potentiality for thinking.

28

Ibid., p. 46

29

Ibid., p. 46 (Capital $A$ in Active intellect is the translator's - interpretative - choice, since in Arabic there are no capital letters).

30

Ibid., p. 46.

31

Ibid., p. 48 (again, capital letters are K. P. Bland's choice). 
to us), as well as in Arabic, there are no capital letters. Averroës (a few lines earlier in the same section of the text) speaks of "apprehension of the lower by the higher", but in no way could it mean 'earthly by celestial', it only means 'a higher form of intellect' and 'a lower form of intellect', active being higher, hylic and acquired being lower, as will be shown. Be that as it may, what Averroës does mean here (in Section seven of the Epistle) by saying that active intellect apprehends the acquired intellect is that the higher aspect (or form) of intellect always "apprehends" the lower aspect (or form) thanks to the mere fact that it is the "higher" aspect (or form), while (as already said) the acquired intellect, being the lower form, can apprehend active intellect as a higher form of intellect only when it reaches its final perfection. What does this mean? What this apprehension of (higher) active intellect by (lower) acquired intellect means has been hinted at by the statement that the function rendering the conjunction by cognizance unique is "nothing other than the conception of the Active Intellect by the acquired intellect". ${ }^{32}$

But first we should see what the 'acquired intellect' means for Averroës. Since the so-called 'hylic intellect' - which received its name because of being passive (hyle being essentially passive, because it is ready to "receive" any possible form) - is man's intellect while only in potentia, not being active, but ready for acquiring intelligibles, that which is called 'acquired intellect' is man's intellect when it has acquired intelligibles. But it should be borne in mind that the acquired intellect still has a character of potentiality, since it can be perfected; the acquiring of intelligibles is only its first entelechy. When it reaches its ultimate entelechy, it - as we have seen - "apprehends" the active intellect. And finally, when the active intellect has been apprehended by the acquired intellect, the latter, says Averroës, is obliterated. So, the acquired intellect is a condition for the coming-to-be of the active intellect. As Averroës says:

"The existence of this intellect [i.e. the acquired intellect] at the level of its first entelechy [i.e. when it conceives intelligibles] is a condition for this [ultimate] existence." ${ }^{\prime 3}$

And he continues reminding the reader that, although the "weaker" form is a condition for the coming-to-be of the "stronger" one, the "stronger" one always does away with the "weaker" one, just as "the existence of the sensible faculty is one of the conditions for the imaginative faculty, after which the sensible no longer remains". ${ }^{34}$ So, when the acquired intellect becomes ready to "apprehend" and does "apprehend" the active intellect, it no longer co-exists with it, as it did when it was not able to cognize it. In a way, it could be said, by "apprehending" the active intellect it becomes it, and, consequently, no longer remains as a lower form; it ceases to exist.

Now, if we recapitulate, we should say the following. Man possesses intellect, which as such is called 'hylic intellect' (compared, because of its potentiality, to hyle as the prime matter which has no form, but potentially is ready to receive any form). When this 'hylic' intellect becomes in actu (i.e. when it begins to cognize real things by producing concepts from them), it becomes 'acquired intellect'. It is clear that 'hylic intellect' and 'acquired intellect' are two aspects - or functions - of the same incorruptible immaterial substance. When this substance finally becomes able to think itself as an immaterial incorruptible substance, it reaches its highest level and is called 'active intellect'. Therefore, Averroës' theory of conjunction with the active intellect is, in fact, a description of the process of man's cognition. This process goes like this: through his senses man perceives things and by the power of his intellect "turns" them into concepts, then "works" with them and produces higher 
notions of immaterial substances, becoming more perfect through this, and finally reaches the highest level by cognizing itself as such a substance. In this process - whose peak is the purpose of man's life - three aspects of man's intellect perform their function, each of them becoming the other, higher aspect: the 'hylic intellect', which - being the universal potential structure of human thinking - for Averroës is 'eternal' and 'incorruptible', the 'acquired intellect', which is intellect in actu, and which - being dependent on bodily faculties - for Averroës is corruptible, and the 'active intellect', which is eternal and incorruptible being, the thinking essence of the immortal soul. He wants to show that man's soul is able to apprehend and cognize separate, immaterial substances, although still being united with the body, because intellect (which is one of the soul's functions) apprehending itself as intellect is apprehending a separate (i.e. immaterial), autonomous substance.

Therefore, one could be fairly certain in saying that, affirming the possibility of conjunction with the active intellect, Averroës did not have in mind a kind of mystic union with a divine substance. The fact that he speaks of 'active intellect' as 'eternal', does not contradict it; we should bear in mind what the notion of 'eternal' here means for Averroës. For him, the 'eternity' of intellect (in its 'guise' of 'active intellect') reflects the fact that intellect is a 'separate' substance (separate from matter, i.e. abstract, and as such 'eternal'). By having itself for the 'object' of apprehension, it 'becomes' one with the object of its own knowledge, and through this becomes 'active intellect', which, as a notion of the 'object' of knowledge, is 'eternal', just as any other notion, because it is not dependent on matter. 'Eternity' of active intellect in 'practical' terms can be understood as eternity of notions, i.e. ideas that, as such, cannot perish, and in speaking of 'possibility' of 'conjunction' with the active intellect Averroës is simply saying that not all men are capable of reaching the highest level of cognizance.

\section{Understandings of active intellect may be different, but its function is one}

In conclusion, it can be said that the issue of the active intellect in Islamic philosophy is not disambiguous. Different philosophers understood this expression differently, for different thinkers it was a different concept. Al-Fārābī, Avicenna, Ibn Țufayl - in congruence with their essentially Neoplatonist emanation theory - speaking of 'active intellect' definitely had in mind a divine, separated, celestial Intellect which acts directly on the sublunar world, among other things by inspiring man's reason in which it produces 'separate', i.e. abstract, notions, enabling it to apprehend "higher" forms. On the other hand, as we tried to show, other thinkers, like Avempace and Averroës, saw the highest function of man's intellect in the 'active intellect', which, by apprehending itself as a 'separated', i.e. abstract, substance, reaches its perfection. As Averroës says in his Middle Commentary on Metaphysics, intervention of a 'separated' (celestial) intellect in the world of generation and corruption is impossible because the action of an immaterial intellect takes place only within itself. If we keep in mind what he says in Tahäfut at-tahäfut-i.e. that

32

Ibid., p. 46.

33

Ibid., p. 50-51.
34

Ibid., p. 51 . 
the cause does not communicate to its effect that which the effect does not possess in itself in potentia - we can conclude that the right interpretation would be that Averroës sees the 'conjunction (ittis $\bar{a} l$ ) with the active intellect' as continuity (which is one of the meanings of ittissa $\bar{l} l$ ) in man's thinking, continuity that brings 'hylic intellect' from perceiving real things, deriving concepts from them, so that it becomes 'acquired intellect', and, finally to think essentially abstract concepts, that have no connection to anything material, and among them thinking/apprehending/cognizing itself as such, reaching by this its highest perfection.

The same can be said of Avempace. Ch. Genequand stresses the fact that Avempace speaks of the 'intellect' in most of cases without any other qualification, disregarding all definitions of different intellects. ${ }^{35}$ So it is no accident that Avempace begins his risāla on The Conjunction of Intellect with Man by explaining the meaning/meanings of the notion of 'one' (wähid), but a necessary introduction to the discussion of 'unity' of intellect, i.e. of showing that intellect is one as a whole is 'one', regardless of the multiplicity of objects it apprehends. When intellect, at the end of its ascension to ever higher degrees, turns to itself, it becomes (according to the Aristotelian theory) 'identical' to itself and its perfect unity comes into being. In the framework of such a process, there is no need for ascension towards a mystic union with a celestial divine entity.

Finally, it should be said that to think ideas means thinking that which is 'separated' (from matter), which is immaterial, which is only thinkable; it means to produce ideas, to produce that which is thinkable. And that is precisely what 'active intellect' does in both types of understanding of what the 'active intellect' is.

\title{
Daniel Bučan
}

'Djelatni um' kod Avempacea i Averroësa: interpretativni problem

\begin{abstract}
Sažetak
Tema ogleda je razumijevanje pojma djelatnog uma u Ibn Bāğğe (Avempacea) i Ibn Rušda (Averroësa). Tradicionalno tumačenje Avempaceova i Averroësova koncepta 'djelatni um'jest da ga obojica razumijevaju kao najnižu nebesku umnost, koja je dator formarum, te da čovjek misli i spoznaje pojamnine jedino "povezujući« se s njime na gotovo mistički način, i da se spoznavanje sastoji u tome da čovjekovu umu djelatni um pribavlja ideje (formae, odnosno pojmove). Autor vjeruje da je i u Avempaceovoj i u Averroësovoj spoznajnoj teoriji pojam djelatnoga uma tek najviša funkcija ljudskoga uma, a ne neki nebeski entitet. Na takovoj pretpostavci te na raščlambi Avempaceove teorije zasniva se tumačenje po kojemu pojam ițișāl bi-'aql fa“"āl nije neka vrsta mističke »spregnutosti«, odnosno »sjedinjenosti«s nekim nebeskim entitetom, nego postizanje najviše razine funkcioniranja čovjekova uma u procesu mišljenja. Isto vrijedi za Averroësovu teoriju koja je prilično jasno izložena u njegovoj Poslanici o sprezi s djelatnim umom, u kojoj se može naći praktično izravna potvrda takove interpretacije, jer Averroës kaže da je »sprezanje s njime, čini se, više nalik spregnutosti oblika s tvarju no što bi bilo nalik sprezi činitelja s učinom. Dobro znana razlika između činitelja i učina je u tome što je činitelj izvanjski, a tu nema takovoga izvanjskog činitelja«, odnosno djelatni um je »s nama povezan od početka povezanošću su-bitka", što znači da je čovjekov um podmet djelatnome umu. Autor zaključuje da pitanje djelatnoga uma u islamskoj filozofiji nije jednoznačno - za razne mislioce to je različit koncept-jedino je funkcija djelatnog uma uvijek jedna ista: proizvođenje ideja.
\end{abstract}

Ključne riječi

spoznaja, tvarni um, odjelovljeni um, djelatni um 


\title{
Daniel Bučan
}

\section{„Aktiver Intellekt“ bei Avempace und Averroës: ein interpretatives Problem}

\begin{abstract}
Zusammenfassung
Dieser Aufsatz handelt vom Verständnis des Begriffs des aktiven Intellekts bei Ibn Bāğğa (Avempace) und Ibn Ruschd (Averroës). Die traditionelle Interpretation von Avempaces und Averroës' Begriff des aktiven Intellekts lautet, beide würden ihn als die niedrigste himmlische Intelligenz auslegen, die dator formarum sei, und der Mensch denke und erkenne Intelligibles nur durch das ,Verbinden " damit in einer quasimystischen Weise, wobei die Erkenntnis darin bestehe, dass der aktive Intellekt dem menschlichen Intellekt Ideen (formae bzw. Begriffe) zukommen lasse. Der Autor glaubt, der Begriff des aktiven Intellekts sei sowohl in Avempaces als auch in Averroës' Erkenntnistheorie erst die höchste Funktion des menschlichen Intellekts, und nicht eine himmlische Entität. Basierend auf einer solchen Vermutung sowie auf der Analyse seiner Theorie wird Avempaces Begriff iț̣ișāl bi-'aql fa“āl nicht als eine Art mystische „Verbindung " oder „Vereinigung “ mit einem separaten himmlischen Wesen interpretiert, sondern als Erreichung der höchsten Ebene der Funktion des menschlichen Intellekts in der Kontinuität des Denkprozesses. Gleiches gilt für Averroës' Theorie, die eher eindeutig in seiner Epistel über die Möglichkeit der Verbindung mit dem aktiven Intellekt ausgebaut wurde, wo man eine praktisch direkte Bestätigung für eine solche Auslegung finden kann, weil Averroës behauptet, „, die Verbindung damit scheint mehr der Verbindung von Form und Materie zu ähneln, als sie der Verbindung von Agens und Wirkung ähnelt. Die wohlbekannte Differenz zwischen Agens und Wirkung besteht darin, dass das Agens extern ist, jedoch gibt es hier kein externes Agens ", bzw. dass der aktive Intellekt ,sich von Anfang an mit uns verbindet durch die Verbundenheit des In-Seins". Der Autor kommt zu dem Schluss, die Frage des aktiven Intellekts in der islamischen Philosophie sei nicht unzweideutig - für unterschiedliche Denker war es ein andersartiges Konzept - lediglich die Funktion des aktiven Intellekts sei stets ein und dieselbe: Ideengenerierung.
\end{abstract}

\section{Schlüsselwörter}

Erkenntnis, Intellekt, hylischer Intellekt, Intellekt in actu, aktiver Intellekt

\section{Daniel Bučan}

\section{« L'intellect agent » chez Avempace et Averroès : problème interprétatif}

\begin{abstract}
Résumé
Cet essai traite de la compréhension du concept d'intellect agent chez Ibn Baja (Avempace) et Ibn Rochd (Averroès). L'interprétation traditionnelle de la notion d'intellect agent chez Avempace et Averroès affirme qu'il s'agit d'une forme d'intelligence céleste inférieure, le dator formarum, et soutient l'idée selon laquelle l'homme pense et connaît les intelligibles uniquement en « se connectant » à lui de manière quasi mystique, la connaissance consistant en ce que l'intellect agent amène les idées (formae, à savoir les concepts) à l'intellect de l'Homme. L'auteur pense que, dans la théorie de la connaissance d'Avempace et dans celle d'Averroès, le concept d'intellect agent représente tout au plus une fonction supérieure de l'intellect humain, et non pas une entité céleste. Sur la base de cette supposition et selon l'analyse de sa théorie, la notion de iț̣ișāl bi-'aql fa“"āl d'Avempace n'est pas une sorte de " jonction » ou d'" union » mystique à une certaine entité céleste, mais plutôt l'acquisition du plus haut niveau de fonctionnement de l'intellect humain au sein du processus de la pensée. Il en va de même pour la théorie d'Averroès qui est peu ou prou exposé dans son Epître sur la possibilité de la jonction, où il est possible de trouver une confirmation presque directe d'une telle interprétation puisqu'il est dit que "la jonction avec l'intellect agent semble davantage ressembler à la jonction de la forme à la matière plutôt qu'à la jonction de l'agent à l'effet. La différence bien connue entre l'agent et l'effet
\end{abstract}


consiste en cela que l'agent est extérieur, alors qu'ici il n'y a pas d'agent extérieur comme tel ", à savoir l'intellect agent « se joint à nous au commencement par la jonction de l'intellect à l'existence ». L'auteur conclut que la question qui se rapporte à l'intellect agent dans la philosophie islamique n'est pas univoque - c'est un concept qui varie selon les auteurs - et que la fonction de l'intellect agent est la seule qui reste toujours la même : la production d'idées.

\section{Mots-clés}

connaissance, intellect matériel, intellect hylique, intellect en acte, intellect agent 